\title{
Metallacycle-Mediated Annulation for the Synthesis of Hydroindanes
}

\section{Key words}

titanium

annulation

hydroindanes

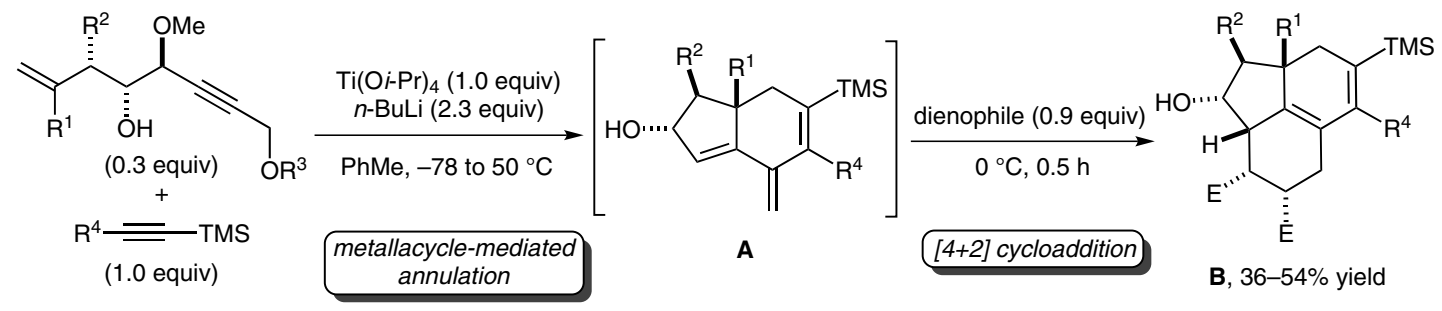

$\mathrm{R}^{1}=\mathrm{Me}, \mathrm{Bn}$

$\mathrm{R}^{2}=\mathrm{H}, \mathrm{Me}, \mathrm{Ph}$

$\mathrm{R}^{3}=\mathrm{Me}, \mathrm{PMB}$

$\mathrm{R}^{4}=\mathrm{Me}, \mathrm{Ph}, 4-\mathrm{BrC}_{6} \mathrm{H}_{4}, \mathrm{CH}_{2} \mathrm{CH}_{2} \mathrm{OPMB}$, i-propenyl

Proposed pathway:<smiles>[R6]OCC#C[C@@H](OC)[C@H](OC)C([R7])C([R])=C</smiles>

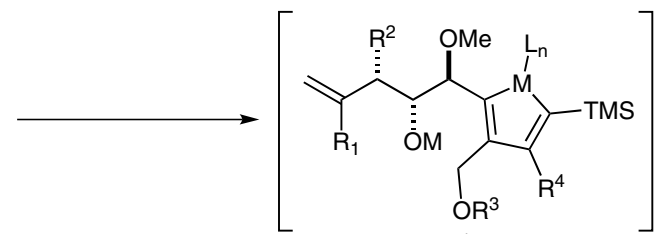

$[\mathrm{M}]=\mathrm{Li}, \mathrm{Ti}$

A<smiles>CCCC</smiles>

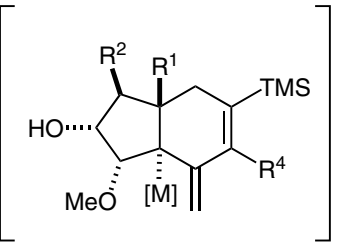

Selected examples:

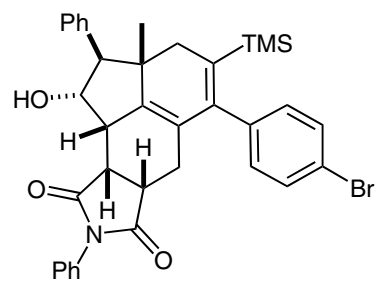

$45 \%$ yield

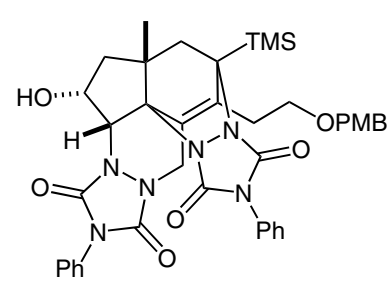

$36 \%$ yield
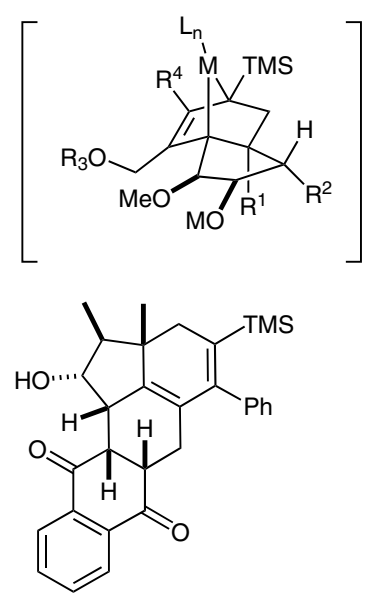

$54 \%$ yield
Significance: Cheng and Micalizio report a stereoselective annulation reaction to afford crossconjugated triene-containing hydroindanes that are subsequently trapped by a dienophile in a [4+2]-cycloaddition reaction to obtain highly functionalized carbo- and heterocyclic systems.

SYNFACTS Contributors: Paul Knochel, Diana Haas

Synfacts 2015, 11(1), $0071 \quad$ Published online: 15.12.2014 Dol: 10.1055/s-0034-1379649; Reg-No.: P15414SF
Comment: The tendency of products of type $\mathbf{A}$ to undergo Diels-Alder-based dimerization upon standing was harnessed to accomplish this reaction cascade of annulation and intermolecular cycloaddition. 